\title{
Front Matter: Volume 11730
}

, "Front Matter: Volume 11730," Proc. SPIE 11730, Big Data III: Learning, Analytics, and Applications, 1173001 (3 May 2021); doi: 10.1117/12.2598598

SPIE. Event: SPIE Defense + Commercial Sensing, 2021, Online Only 


\section{PROCEEDINGS OF SPIE}

\section{Big Data III: Learning, Analytics, and Applications}

Fauzia Ahmad

Panos P. Markopoulos

Bing Ouyang

Editors

12-16 April 2021

Online Only, United States

Sponsored and Published by

SPIE 
The papers in this volume were part of the technical conference cited on the cover and title page. Papers were selected and subject to review by the editors and conference program committee. Some conference presentations may not be available for publication. Additional papers and presentation recordings may be available online in the SPIE Digital Library at SPIEDigitalLibrary.org.

The papers reflect the work and thoughts of the authors and are published herein as submitted. The publisher is not responsible for the validity of the information or for any outcomes resulting from reliance thereon.

Please use the following format to cite material from these proceedings:

Author(s), "Title of Paper," in Big Data III: Learning, Analytics, and Applications, edited by Fauzia Ahmad, Panos P. Markopoulos, Bing Ouyang, Proc. of SPIE 11730, Seven-digit Article CID Number (DD/MM/YYYY); (DOI URL).

ISSN: 0277-786X

ISSN: 1996-756X (electronic)

ISBN: 9781510642973

ISBN: 9781510642980 (electronic)

Published by

SPIE

P.O. Box 10, Bellingham, Washington 98227-0010 USA

Telephone +13606763290 (Pacific Time)

SPIE.org

Copyright @ 2021 Society of Photo-Optical Instrumentation Engineers (SPIE).

Copying of material in this book for internal or personal use, or for the internal or personal use of specific clients, beyond the fair use provisions granted by the U.S. Copyright Law is authorized by SPIE subject to payment of fees. To obtain permission to use and share articles in this volume, visit Copyright Clearance Center at copyright.com. Other copying for republication, resale, advertising or promotion, or any form of systematic or multiple reproduction of any material in this book is prohibited except with permission in writing from the publisher.

Printed in the United States of America by Curran Associates, Inc., under license from SPIE.

Publication of record for individual papers is online in the SPIE Digital Library.

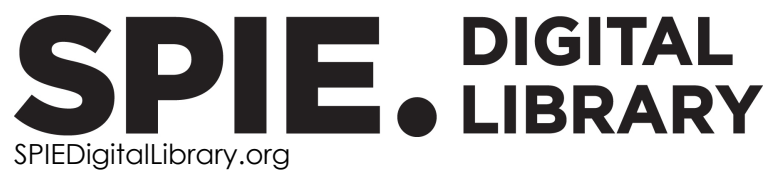

Paper Numbering: A unique citation identifier (CID) number is assigned to each article in the Proceedings of SPIE at the time of publication. Utilization of CIDs allows articles to be fully citable as soon as they are published online, and connects the same identifier to all online and print versions of the publication. SPIE uses a seven-digit CID article numbering system structured as follows:

- The first five digits correspond to the SPIE volume number.

- The last two digits indicate publication order within the volume using a Base 36 numbering system employing both numerals and letters. These two-number sets start with 00, 01, 02, 03, 04, 05, 06, 07, 08, 09, 0A, OB ... 0Z, followed by 10-1Z, 20-2Z, etc. The CID Number appears on each page of the manuscript. 


\section{Contents}

\section{SESSION $1 \quad$ MACHINE LEARNING}

1173002 Image denoising via patch based $\mathrm{L}$-norm principal component analysis [11730-1]

1173003 A machine learning approach to medical data identification through principal component analysis [11730-2]

1173004 Multi-frame GAN-based machine learning image restoration for degraded visual environments [11730-3]

1173005 Radar human motion classification using multi-antenna system [11730-4]

\section{SESSION 2 HARDWARE IMPLEMENTATION AND SYSTEM DESIGN}

1173007 Development of a macroalgal biomass sensor for an integrated multi-trophic aquaculture (IMTA) system [1 1730-6]

1173008 Development of a low-cost subsea datalogger for passive phased sonar arrays [11730-7]

$1173009 \quad$ An efficient low-cost notification system using AWS lot [1 1730-8]

SESSION 3 BIG DATA ANALYTICS

11730 OC Uncertainty contribution estimation for Monte Carlo uncertainty quantification via subspace analysis: neutronics case study [11730-11]

11730 OD Comparison of CP and Tucker tensor decomposition algorithms [11730-12]

11730 OE Multi-Agent Systems (MAS) related data analytics in the Hybrid Aerial Underwater Robotic System (HAUCS) [11730-13]

SESSION 4 BIG DATA PROCESSING

11730 OF Pooled testing with compressive sensing [11730-14]

11730 OG Determination of the number of clusters by symmetric non-negative matrix factorization [11730-15] 
$11730 \mathrm{OH} \quad$ Road network detection based on improved FLICM-MRF method using high resolution SAR images [11730-16]

\section{SESSION 5 DEEP LEARNING}

11730 0J Hierarchical motion-compensated deep network for video compression [11730-18]

11730 OK Neural network image fusion with PCA preprocessing [11730-19]

$117300 \mathrm{M}$ On the robustness of high-resolution cervical auscultation-based detection of upper esophageal sphincter opening duration in diverse populations [11730-21]

$11730 \mathrm{ON} \quad$ Evaluation of a technique to simulate LiDAR image datasets for training a machine learningbased image enhancement algorithm [11730-22]

\section{POSTER SESSION}

$1173000 \quad$ Single neuron-based neural networks are as efficient as dense deep neural networks in binary and multi-class recognition problems [11730-23] 